\title{
When stones are no longer stones
}

\author{
E. Zapatero \\ Polytechnic University of Madrid (UPM), Spain
}

\begin{abstract}
Amongst the various architectural heritage objects, stone building forms are recursive regardless of their dressing and bond. Many of these constructions are subject to restoration interventions which apply consolidation techniques and criteria that can affect the characteristics of these stone constructions, favouring their preservation or, on the contrary, reducing or destroying their intrinsic values.

On the other hand, Brandi claims that the artistic object consists of image and matter, matter being the support for the manifestation of the image. This formulation, which he also applies to architectural objects, continues by stating that matter unfolds in material appearance and material structure. However, matter is not only the support for the image and artistic values, but also contains great documentary value both in its structure and appearance. Based on this definition, this paper will decipher the characteristics of historical masonries, analysing interventions on architectural heritage and how the application of different consolidation techniques affect the documentary value of the matter. This will lead to conclusions regarding which techniques are suitable for preserving the masonry's, identifying in which cases stones no longer fulfil the functions for which they were originally employed. When this happens, stones lose their purpose, they may seem like pieces of a constructive and mechanical system that has currently ceased to exist. This could lead to a misinterpretation of the building, reducing its integrity and documentary authenticity.
\end{abstract}

Keywords: masonry walls, consolidation technique, documentary value, restoration, conservation.

\section{Introduction}

On my visit to the Acropolis of Athens a few years back with a fellow architecture student, walking by the Erechtheion and the Parthenon we heard a couple of tourists speak; she asked "How did the ancient Greeks hold together the stones 
from these temples?", and he replied: "with cement, of course". My partner and I looked at each other amused and repeated: "of course!"

Years later, while researching on consolidation techniques used in architectural heritage, I studied the charters of Athens (1931) and Rome (1972) and their recommendations about materials referred to as "modern" in restoration and the intervention conducted by N. Balanos on various Acropolis temples. To my surprise, I realized that those tourists were not as wrong as I thought they were, and that the descriptions found in history construction books, regarding construction systems employed in buildings from the Acropolis, did no longer match the existing reality. I discovered then that some stones contain fewer values than others, and that others can cease being stones.

The study presented in this article comes from the analysis of the role played by stone or ceramic elements in historic masonries. These elements were originally part of a construction and mechanical system that reflected the way things were done at that time. These masonries have therefore a documentary value as testimonies of these constructions from the past. This article will analyse some of the techniques used for consolidation of masonries from different buildings which are part of our architectural heritage. It will explore the effect that such techniques can have over the components of the masonry and how these effects can influence the preservation of the building documentary value. From this information we will extract data that will help in the preservation of this value, therefore helping preserve the authenticity of our architectural heritage, understood as the integrity of all the intrinsic values that it contains.

\section{Methodology}

This study's methodology is based on the definition of the artistic object by Brandi who states that it is made up from image and matter, the latter being the support for the manifestation of the image. Matter, in turn, unfolds into material appearance and material structure (Brandi [1]). However, matter is not only support for the image and the artistic values of the object. It also contains a documentary value and should be preserved in its entirety. Matter in its appearance contains signs of aging such as deformation, cracks, patina, etc. that allow us to understand the process of the building transformation. Matter in its structure is testimony to construction and mechanical systems employed in the past. The following sections will analyse the impact that different consolidation techniques have had over matter from historic masonries, in both its appearance and structure, verifying whether or not the stone elements that build them still retain their values and meaning.

\section{Case studies}

\subsection{External consolidations}

In 1996, a consolidation intervention was required in the transverse wall from the palace of the governor in the architectural compound Forte di Fuentes in Colico, 
northern Italy. It was a ten meter high free standing, slender wall with a thickness of less than $60 \mathrm{~cm}$ in many areas. The heterogeneity of the masonry, the lack of cohesion between its parts and the cavities it had were factors that endowed the element with little stability. This was exacerbated by its exposure to strong winds without any perpendicular wall to make it a "box" resistant to horizontal actions (Jurina [2]). The decision in this consolidation by Jurina was to consolidate the masonry with vertical steel cables arranged parallel to each other longitudinally along the wall. These cables were anchored to the ground in its lower part and bound to the masonry with metallic spacers. The aim was to create a parallel structure to collaborate with the masonry in the presence of exceptional efforts. The steel cables would be set on both sides of the masonry to face the wind that came from both directions.

This consolidation manages to respect both artistic and documentary values from the masonry, keeping all its matter almost without interfering in its image. The steel cables collaborate with the existing mechanical system without altering matter in its structure, which retains its documentary values, including information about its construction and mechanical systems. Additionally, the consolidation maintains matter in its appearance together with the documentary value from the traces that time has left on the masonry.

\subsection{Integrated consolidations}

In 1764 Heidelberg Castle suffered extensive damage from the impact of two lightning bolts. These damages are added to the ones from the Franco-Prussian war between 1870 and 1871. Between 1897 and 1903 the Fiedrichsbau, one of the most representative buildings in the complex, is rebuilt. The decision in this intervention conducted by Schäfer was to use stone replacement techniques that provided the building a renewed aspect. Almost one third of the damaged stones are replaced (Hubel [3]), thereby erasing traces of war such as marks from fire, explosions, gunshots, etc. By removing the traces of this historical stage, the documentary value of the building from matter in its appearance is irreversibly reduced.

Another case where this technique was applied extensively was in Frankfurt's Old Opera building. After the 1944 bombing, the inside of the building suffered extensive damage, leaving only the building envelope standing. The restoration of the building was commissioned in 1971 to the architectural firm Braun and Schlockermann, and included an ambitious cultural program inside the building. Replacement techniques are applied in the consolidation of the south facade on approximately $1500 \mathrm{~m}^{2}$ of sandstone (Brix [4]).

Many interventions were conducted after World War II on representative buildings in Germany using these replacement techniques, which allowed to present matter with a renewed appearance that little reminds us of this tragic episode in history. 


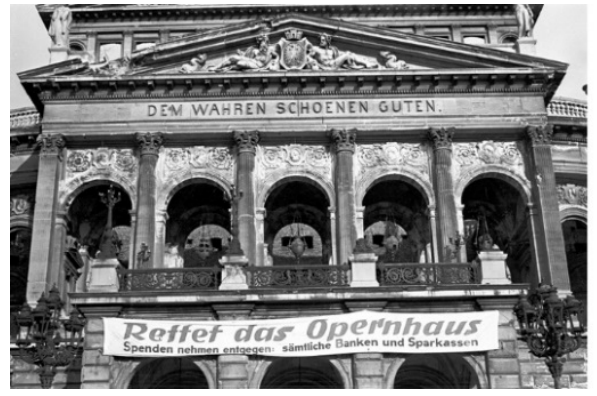

Figure 1: Old Opera in Frankfurt: matter in its appearance shows traces of World War II (picture: K. Liese, HaraldReportagen).

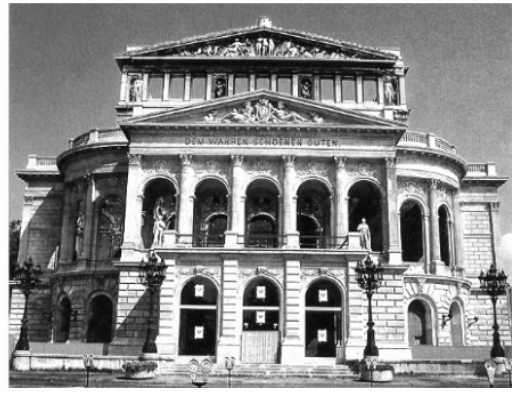

Figure 2: Old Opera in Frankfurt: substitution techniques erase war traces, damaging documentary value of matter in its appearance (picture: Brix [4]).

\subsection{Hidden consolidations}

In 1981 the architects Araujo and Nadal consolidated the masonries that make up the tower of the Sta. Maria de Alcocer Church in the Spanish province of Guadalajara. The solution is to apply "modern" concrete injections and stitching techniques inside the masonries, tying up the walls from the tower. This technique manages to keep matter in its appearance, displaying the damage that led to the consolidation of the element. These visible signs of damages have a documentary value themselves. The cracks, deformation, etc. are frozen at the time of the intervention interrupting its evolution. However, matter in its structure is destroyed irreversibly, by altering its historic construction and mechanical systems.

\section{Discussion and conclusions}

As explained in the previous sections, an external and distinguishable technique is used in the consolidation of the masonries from Forte di Fuentes. This technique works with the masonry without replacing its original construction and mechanical system. Matter is preserved in its entirety. After consolidation, the stones that make up the masonry are still stones that retain their documentary value entirely.

When replacement techniques are used, the matter in its appearance is removed, damaging its documentary value irreversibly. In the examples shown, the main goal was to eliminate the traces of the war. However, this technique has also eliminated other documentary values like patinas, quarry marks, damages, etc. that enable the study of the age of the building, its process of creation and transformation, etc. When these techniques are applied over extensive areas, as is the case of the examples described, one can achieve a complete replacement of 
matter obtaining a replica in both, its appearance and structure. The intervention at Friedrichsbau at the Heidelberg Castle is criticized in this sense in several reviews of the time. Perhaps the most representative comes from the art historian Georg Dehio, who censures this attempt to correct history retroactively on uncertain basis, losing authenticity to obtain an imitation (Dehio [5]). However, this does not happen when these techniques are applied in a traditional way, through localized repairs with substitutions limited to the damaged areas. These replaced stones become a new layer in the transformation of the building. A layer which in turn erases the manifestation of the damage that led to the substitution intervention. However, the new stones remain acting as stones, although with reduced documentary values. They are still stones in a historic construction and mechanical system that manage to preserve the documentary value of matter in its structure.

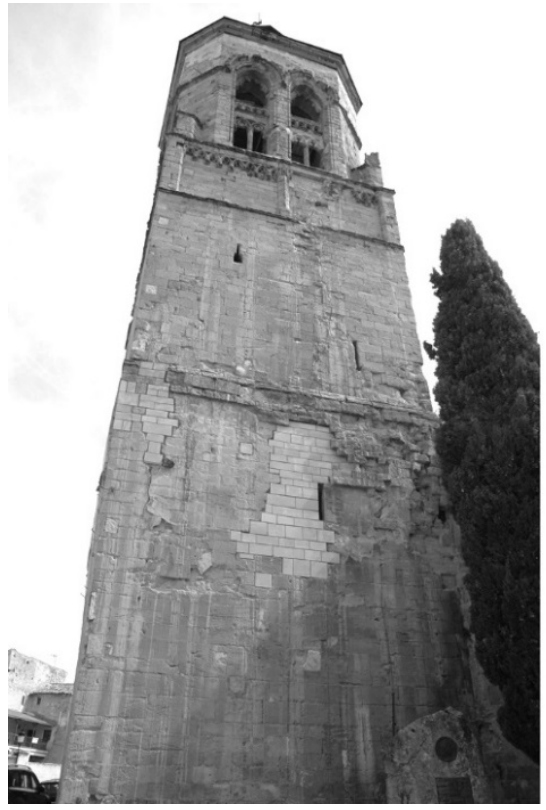

Figure 3: Tower of Sta. Maria de Alcocer consolidated with hidden techniques that can preserve documentary value of matter in its appearance.

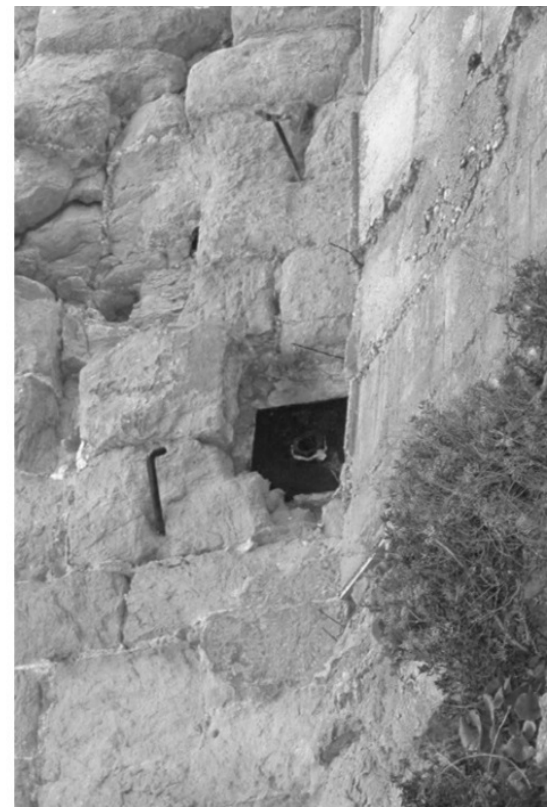

Figure 4: Tower of Sta. Maria de Alcocer: steel stitching rod anchored to masonry transforming matter in its structure irreversibly.

The last example describes a hidden consolidation based on the use of reinforced concrete. When these "modern" techniques began to be employed to consolidate historical masonries, it was adopted as the ideal formula for restorations (López Otero [6]), as it allowed to apply consolidations with no visible 
effect over the image of the masonry. However, over time these techniques began to show incompatibilities with historic masonries, which manifested as material rejection, broken structures, etc. These techniques, which initially appeared to be more respectful with historic masonries than traditional techniques, caused them major damage over time with the aggravation of being irreversible.

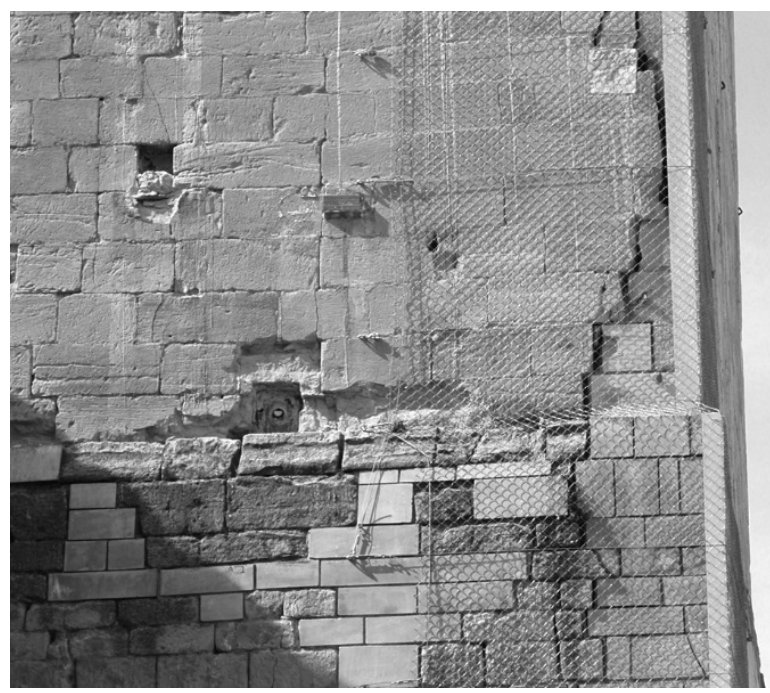

Figure 5: Tower of Sta. Maria de Alcocer: Damages caused by incompatible consolidation techniques manifest on matter in its appearance.

The consolidation over the tower of the Sta. Maria de Alcocer Church is an example of the damage that this technique can cause on historical masonries. Incompatibility between the new material and the historic masonry manifests in the image of the masonry and in the matter in its appearance through cracks and rejection of its material. Over time, the materials and execution process from this technique has been improved, and is now capable of keeping the image of these masonries and their matter in its appearance unaltered. However, although the damage may not be visible, matter in its structure is destroyed irreversibly. These stones that look like stones ceased to be stones belonging to an isostatic mechanical system, and became material in a new statically indeterminate mechanical system which is strange to them. In this new matter, the original meaning from these stones is lost. This new decorative function is misleading, since matter in its appearance is made up of these stones, with their patina, their damages, quarry marks, appearing to still be what they once were. However, when stones are no longer stones, we can no longer rely on them, study them and let them reveal us the secrets about how they work. We will be limited to study what the history books say. 


\section{References}

[1] Brandi, C., Teoría de la restauración, Alianza Editorial: Madrid, p. 149, 2002.

[2] Jurina, L., Forte di Fuentes a Colico, un consolidamento in itinere. Structural ed. De Lettera, 175, p. 18, 2013.

[3] Hubel, A., Denkmalpflege: Geschichte - Themen - Aufgaben. Eine Einführung, Phillip Reclam jun. GmbH \& Co. KG: Stuttgart, p. 421, 2011.

[4] Brix, M., Frankfurt: Alte Oper. Kontroversen um einen Repräsentationsbau der Gründerzeit, At Denkmalpflege in der Bundesrepublik Deutschland. Geschichte, Organisation, Aufgaben, Beispiele. Heinz Moos Verlag: München, pp. 32-33, 1974.

[5] Dehio, G., Was wird aus dem Heidelberger Schloss werden? (1901), At Hanselmann, J.F. (dir.) Rekonstruktion in der Denkmalpflege. Texte aus Geschichte und Gegenwart. Fraunhofer IRB Verlag: Stuttgart, pp. 24-32, 2009.

[6] López Otero, M., La técnica moderna en la conservación de monumentos. Discursos leídos ante la Academia de la Historia. Artes Gráficas Faure: Madrid, pp. 6-22, 1932. 